\title{
EFFECT OF CULTURAL PRACTICES AND FERTILIZERS ON SUNFLOWER YIELDS IN LONG TERM EXPERIMENTS
}

\author{
Petcu, Gh. ${ }^{*}$ and Petcu, E. \\ Agricultural Research and Development Institute (ARDI), \\ Fundulea, 915200, Romania
}

Received: September 10, 2005

Accepted: March 25, 2006

SUMMARY

Field experiments were conducted during 1980-2004 at Agricultural Research and Development Institute from Fundulea (Romania) on a leached chernozem soil, well drained, formed on loess, with $33 \%$ clay content and $2.8 \%$ organic matter in the arable layer. The paper presents aspects regarding the influence of different soil tillage methods (moldboard plow, chisel, paraplow, disking), fertilizers and track by track successive passings of tractor (from 1 to 3) prior to seedbed preparation on sunflower yield under dryland conditions. The developed modern crop production technologies should be improved in response to concerns about environmental impacts of agriculture towards cropping intensification reduction. In this context, choice of a good soil tillage method management is an important decision to improve grain yield and quality. Continuous implementation of optimal rates of fertilizers (from different chemical types or manure) helps us to obtained more efficient sunflower cropping systems. The wheel pressure induces a soil compaction down to $40 \mathrm{~cm}$ depth, emphasized by an increase of bulk density and a decrease of total and air porosities below the minimum level needed for normal crop development. The plant height and leaf area were reduced by compaction, as a result of deteriorated soil conditions for root growth. The root biomass was lower by 16 $33 \%$ in compacted soil as compared with non-compacted one.

Key words: crop rotation, soil compaction, fertilizer, root development, biomass accumulation, oil content

\section{INTRODUCTION}

Plant-available water is the most limiting factor to yield potentials of dryland agriculture in semiarid regions. Therefore, in the semiarid South Great Plains of Romania, water is often the primary factor influencing management decisions concerning appropriateness of cropping systems and crop selection within cropping

* Corresponding author, Fax: 0040242 642044; e-mail: petcug@ricic.ro 
systems. Besides the latest movement in land property registered in Romania and the lack of founds which determined farmers of many agricultural zones to increase the area planted to sunflowers give presently more problems in crop rotation. Our objective was to compare the trends of sunflower yields from different treatments in long-term experiments conducted in the last two decades. A large scale for climatic parameters in South of Romania, registered year by year, in trial experimentation period requires new strategies in sunflower cropping in strong dependence with local conditions.

Crop selection and management strategies for tillage, weeds, organic matter, fertilizers and residue that will give the most effective use of water are needed (Stone et al., 2000).

On the other side, an intensive traffic with tractors and other farm vehicles over arable land leads to soil compaction. Wheel pressure causes a decrease in soil porosity which affects crop development. The degree of compaction depends directly on the magnitude of the pressure forces, soil type and its moisture.

The effect of soil compaction on soil fertility and crop yield was studied by several authors (Barnes et al., 1971; Eriksson et al., 1974; Soane et al., 1982; Boone, 1986; Hakansson et al., 1988; Sin et al., 1989, 1991). According to their data, soil compaction determines the rate of deterioration of soil properties regarding water and air movement and nutrient regime, hinders root growth and brings yield losses.

Although the compacted soil is loosened by plowing, the soil conditions can became unfavorable for plant growth because a pan may develop in the unworked subsoil, with impaired structure specific for the compacted soil.

The paper presents some aspects concerning the response of sunflower to different cropping systems and soil compaction intensity.

\section{MATERIALS AND METHODS}

\section{The site}

A trial was conducted between 1989-2004 at Agricultural Research and Development Institute, Fundulea ( $44^{\circ} 27^{\prime} \mathrm{N} 26^{\circ} 31^{\prime} \mathrm{W}, 67 \mathrm{~m}$ above sea level). The soil in the location was mapped as a moderately leached chernozem soil, well-drained, formed on loess, with $33 \%$ clay content and $2.8 \%$ organic matter in arable layer.

The climate is classified as "DFAX type" (de Martonne classification), with high inequalities for monthly rainfall repartition during year. The annual rainfall during the trial was characterized by large variability between years and among months in the same year. Data from Figure 1 have indicated the highest value for rainfall during sunflower vegetation in $1991(572 \mathrm{~mm}$ ) vs. $305 \mathrm{~mm}$ for the trial period average 1987-2004, up to $8 \mathrm{~mm}$ higher than long-term average, noticed at Fundulea (19602004). 
Generally, the average monthly air temperatures were higher in the latest decade than the long-term average $\left(+1.2^{\circ} \mathrm{C}\right)$.

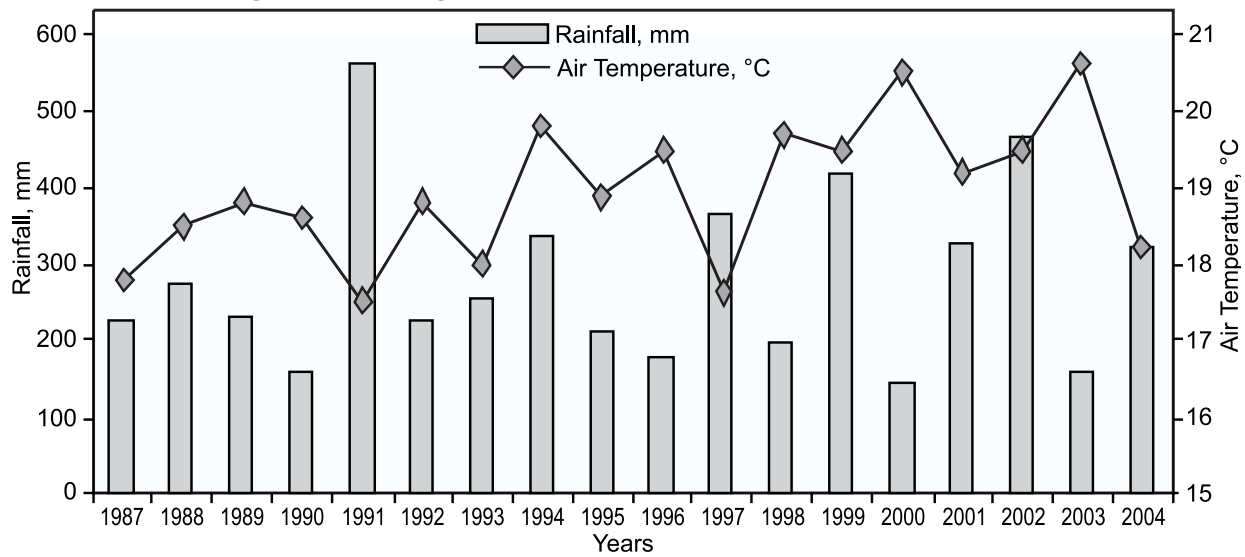

Figure 1: Mean annual rainfalls and air temperatures during vegetation seasons for the experimental period

\section{Treatments and experimental design}

The experimental schedule consists of main cultural practices: crop rotation, soil tillage method, fertilizers and soil compaction.

The compaction treatments were tested in a fall-plowed field, by successive passings of a tractor U-650 (of $3800 \mathrm{~kg}$ weight) in the spring, prior to seedbed preparation.

The various degrees of compaction were obtained by four wheel traffic treatments:
a. - unwheeled $\left(\mathrm{C}_{0}\right)$;
b. - one pass of tractor, track by track $\left(\mathrm{C}_{1}\right)$;
c. - two passes of tractor $\left(\mathrm{C}_{2}\right)$;
d. - three passes of tractor $\left(\mathrm{C}_{3}\right)$.

After soil compaction, seedbed preparation was performed by disking. The crop technology was normal, regarding sowing time (during 15-20 April), plant density ( 4.6 plants $\left./ \mathrm{m}^{2}\right)$, fertilization $\left(\mathrm{N}_{100} \mathrm{P}_{75}\right)$ and weed control (chemical and mechanical methods).

\section{Determinations}

Soil samples were collected for determination of bulk density immediately after soil compaction and at harvest. Taking into account the values of bulk density, the total and air porosities were indirectly determined.

Observations and measurements concerning plant emergence, plant growth, root development, yield components and main indicators of yield were also made. 
At flowering, the root growth was assessed by the endoscopic method, in the area round the plant in 0-60 $\mathrm{cm}$ layer.

The experiment was stationary, organized in a 6-year rotation (maize after winter wheat) and designed in randomized blocks in 4 replications. The size of experimental plot was of $120 \mathrm{~m}^{2}$.

\section{Statistical analysis}

The data obtained during the trial were subjected to the analysis of variance, using ANOVA test statistical procedures. Differences among the treatments were evaluated with the least significance difference test (LSD), each mean being compared with the experiment mean or a control value. Pearson correlation coefficients were used to compare yield performance against some qualitative and growth parameters. All discussed differences were significant at the $\mathrm{P}=0.05$ probability level.

\section{RESULTS AND DISCUSSION}

Effect of soil compaction on main physical soil indices, plant growth, yield production and quality for sunflower cropping.

Table 1: Effect of soil compaction on the main physical indicators of the soil (before sowing), Fundulea, 1987-2004

\begin{tabular}{lccccc}
\hline \multirow{2}{*}{ Variant } & Depth & Soil moisture & Bulk density & Soil porosity & Air soil porosity \\
\cline { 2 - 6 } & $\mathrm{cm}$ & $\%$ & $\mathrm{~g} / \mathrm{cm}^{3}$ & $\%$ & $\%$ \\
\hline $\mathrm{C}_{0}$ & $0-10$ & 22.0 & 1.22 & 52.3 & 21.6 \\
& $10-20$ & 23.7 & 1.31 & 50.0 & 14.8 \\
& $20-30$ & 23.9 & 1.38 & 47.5 & 10.7 \\
& $30-40$ & 24.0 & 1.41 & 46.2 & 7.3 \\
\hline $\mathrm{C}_{1}$ & $0-10$ & 22.5 & 1.41 & 44.4 & 6.9 \\
& $10-20$ & 23.9 & 1.46 & 44.5 & 5.3 \\
& $20-30$ & 23.5 & 1.47 & 44.2 & 4.8 \\
& $30-40$ & 23.8 & 1.45 & 44.9 & 5.0 \\
\hline $\mathrm{C}_{2}$ & $0-10$ & 22.3 & 1.43 & 43.1 & 5.9 \\
& $10-20$ & 23.6 & 1.47 & 43.6 & 4.3 \\
& $20-30$ & 23.5 & 1.46 & 43.7 & 3.8 \\
& $30-40$ & 23.4 & 1.45 & 44.1 & 3.6 \\
\hline $\mathrm{C}_{3}$ & $0-10$ & 22.2 & 1.51 & 42.9 & 4.5 \\
& $10-20$ & 23.7 & 1.48 & 43.1 & 3.0 \\
& $20-30$ & 23.4 & 1.47 & 43.3 & 3.7 \\
& $30-40$ & 23.3 & 1.46 & 43.9 & 3.3 \\
\hline
\end{tabular}

Table 1 presents the evolution of the main physical indicators of the soil during 1987-2004. In the non-compacted variant, the total air porosity is diminished into soil, from 0 to $40 \mathrm{~cm}$, while the bulk density increased from $1.22 \mathrm{~g} / \mathrm{cm}^{3}$ in the 
superficial layer to $1.41 \mathrm{~g} / \mathrm{cm}^{3}$ into its depth $(30-40 \mathrm{~cm})$. In variant $\mathrm{C}_{1}$, with compacted soil and with its bulk density of $1.43 \mathrm{~g} / \mathrm{cm}^{3}$, the air porosity was strongly diminished and in $\mathrm{C}_{3}$ variant these features were very much under the values registered in non-compacted variant. The increase of the volumetrical weight and the reduction of the total air porosity in the compacted variants influenced the growth and development of the root system (Table 1).

The root area and biomass accumulation have showed an important decrease in the case of variant $\mathrm{C}_{3}$ in the top layer of the soil (from 0 to $10 \mathrm{~cm}$ ).

One can notice the increasing tendency of the root matter in the $20-30 \mathrm{~cm}$ layer, where the compaction has not affected the structure of the soil.

Taking into account the entire weight of the root for each plant, on the whole depth of the tested soil, an important reduction in root weight in the third variant of soil compaction.

The total surface of the root registered an important increase in the variant of slight compaction $\left(\mathrm{C}_{1}\right)$ and a distinct reduction in the case of $\mathrm{C}_{3}\left(1.50 \mathrm{~g} / \mathrm{cm}^{3}\right)$, (Table 2).

In the variant of severe compaction $\left(\mathrm{C}_{3}\right)$, the root makes greater efforts, which calls for a high energy consumption and which has negatively affects root growth (Russell, 1977).

Table 2: Effect of soil compaction on root growth of sunflower (before 10-leaf stage)

\begin{tabular}{lccc}
\hline \multirow{2}{*}{ Depth, cm } & \multicolumn{3}{c}{ The root area, $\mathrm{cm}^{2} /$ plant } \\
\cline { 2 - 4 } & $\mathrm{C}_{0}$ & $\mathrm{C}_{1}$ & $\mathrm{C}_{3}$ \\
\hline $0-10$ & 1286 & 1341 & 796 \\
$10-20$ & 374 & 353 & 210 \\
$20-30$ & 348 & 397 & 92 \\
$30-40$ & 208 & 217 & 198 \\
$40-50$ & 172 & 194 & 114 \\
$50-60$ & 112 & 143 & 131 \\
Total & 2500 & $2645^{*}$ & $1541^{000}$ \\
\hline LSD P $<0.05 \%$ & \multicolumn{3}{l}{140 (cm $/$ plant) }
\end{tabular}

\begin{tabular}{ccc}
\multicolumn{3}{c}{ Biomass accumulation in root, dry } \\
\hline $\mathrm{C}_{0}$ & $\mathrm{C}_{1}$ & $\mathrm{C}_{3}$ \\
\hline 11.5 & 9.4 & 7.1 \\
2.7 & 1.5 & 1.6 \\
2.3 & 2.2 & 2.1 \\
2.1 & 1.8 & 1.2 \\
1.5 & 1.7 & 1.1 \\
0.8 & 0.5 & 0.3 \\
20.9 & $17.1^{0}$ & $13.4^{00}$ \\
\hline \multicolumn{3}{c}{3.1 (DM g/plant) }
\end{tabular}

Table 3: Indices of sunflower growth, at flowering stage, depending on the soil compaction (variation limits during the experimental period)

\begin{tabular}{lccc}
\hline Treatment & $\begin{array}{c}\text { Number of plants/ha } \\
\times 1000\end{array}$ & $\begin{array}{c}\text { Plant height, } \\
\mathrm{cm}\end{array}$ & $\begin{array}{c}\text { Leaf area, } \\
\mathrm{cm}^{2} / \text { plant }\end{array}$ \\
\hline $\mathrm{C}_{0}$ & 44.6 & $168-185$ & $3210-3460$ \\
$\mathrm{C}_{1}$ & 40.7 & $151-163$ & $2920-3100$ \\
$\mathrm{C}_{3}$ & 39.5 & $147-159$ & $2780-3020$ \\
\hline
\end{tabular}

Coming back to the effect of the diminution of the root matter reduction determined by the narrowing of the spaces between soil aggregates and of the air porosity both on growth plant and green matter, we can notice that this effect appears still from first stage of vegetation. Thus, plant height, leaf area, biomass accumulation and yield are negatively influenced by soil compaction during the flowering stage (Table 3). 
It is obvious that in both cases of soil compaction, slight $\left(C_{1}\right)$ and severe $\left(C_{3}\right)$, dry matter accumulation is decreased not only in the root but also in the shoot and leaves, this proving that the physiological activity of the plant is affected, a great part of its assimilates being necessary to obtain the energy for root penetration.

Concerning grain yield, it was evidently reduced in all variants of compaction and was influenced also by weather conditions (Table 4).

Table 4: Effect of soil compaction on sunflower yield (in kg/ha), Fundulea, 1995-2004

\begin{tabular}{|c|c|c|c|c|c|}
\hline \multirow{2}{*}{ Year of experiment } & \multicolumn{4}{|c|}{ Treatment } & \multirow{2}{*}{$\begin{array}{l}\text { Average } \\
\text { per yea }\end{array}$} \\
\hline & $\mathrm{C}_{0}$ & $\mathrm{C}_{1}$ & $\mathrm{C}_{2}$ & $\mathrm{C}_{3}$ & \\
\hline$\overline{1995}$ & 2130 & 2260 & 2260 & 2050 & 2175 \\
\hline 1996 & 1590 & 1250 & 1200 & 1010 & 1263 \\
\hline 1997 & 1690 & 1600 & 1360 & 1230 & 1470 \\
\hline 1998 & 2540 & 2430 & 2270 & 2360 & 2400 \\
\hline 1999 & 1960 & 2190 & 2330 & 2210 & 2173 \\
\hline 2000 & 1340 & 1610 & 1580 & 1360 & 1473 \\
\hline 2001 & 1470 & 1260 & 1300 & 1150 & 1295 \\
\hline 2002 & 940 & 1070 & 1140 & 1340 & 1123 \\
\hline 2003 & 1170 & 1670 & 1450 & 1090 & 1345 \\
\hline 2004 & 2500 & 2590 & 2420 & 2240 & 2438 \\
\hline Average period & 1733 & 1793 & 1731 & $1604^{0}$ & \\
\hline LSD $P<0.05 \%$ & \multicolumn{4}{|c|}{$110(\mathrm{~kg} / \mathrm{ha})$} & \\
\hline
\end{tabular}

These results have been confirmed by other researchers, who emphasized that the first element, which acts as a stressing element for root, is the oxygen content from the soil (Hoffmann, 1982, Gay, 1999).

The changes that occurred in sunflower plants under conditions of soil compaction positively affected the oil content in seeds (Figure 2).
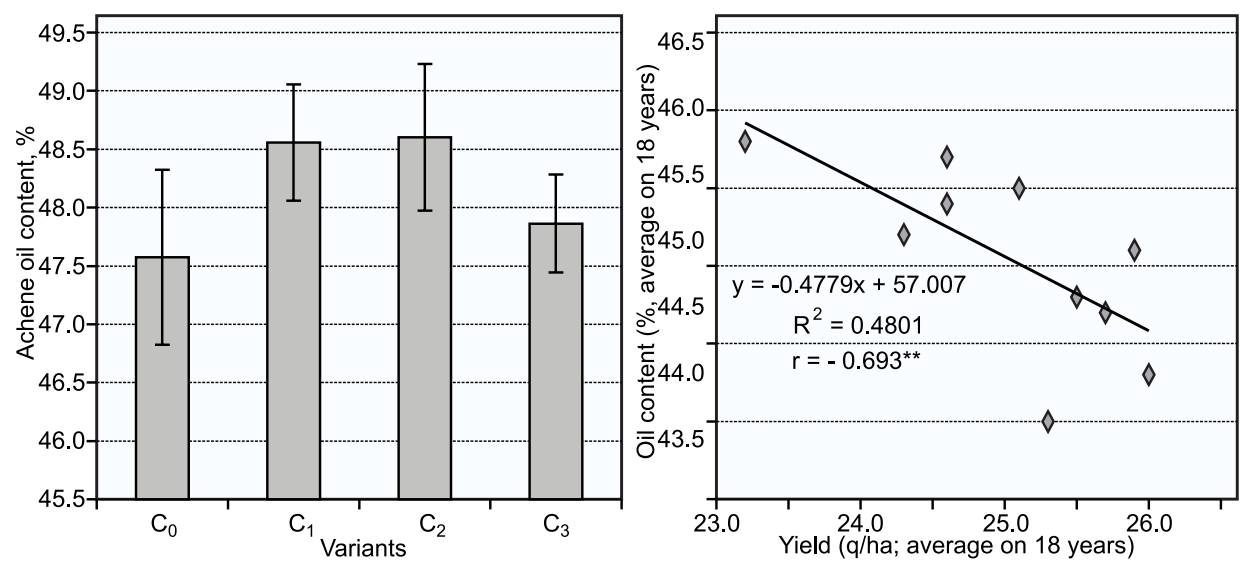

Figure 2: Effect of soil compaction on achene Figure 3: Relationship between yield and oil content (nine-year average) achene oil content of sunflower 
Our results confirmed that yield and oil content were negatively and significantly correlated (Figure 3 ).

Effect of alternation soil tillage methods and fertilizers on yield production in dryland experiments

Only one disking of the soil as well as more ones, surely generate similar situations to the above mentioned cases.

Analyzing the root system distribution in different depths in the case when the soil was only disked before sowing, a reduction in root area was observed in comparison with the plowed variants (Table 5).

Table 5: Effect of soil tillage on some features of sunflower plants

\begin{tabular}{|c|c|c|c|c|c|}
\hline Variant & $\begin{array}{c}\text { Root area }\left(\mathrm{cm}^{2} / \mathrm{pl}\right) \\
\text { in top soil layer } \\
(0-20 \mathrm{~cm})\end{array}$ & $\begin{array}{l}\text { Yield, } \\
\text { Q/ha }\end{array}$ & $\begin{array}{l}\% \text { from } \\
\text { control }\end{array}$ & $\begin{array}{c}\text { Oil content, } \\
\%\end{array}$ & $\begin{array}{l}\text { Oil yield, } \\
\text { I/ha }\end{array}$ \\
\hline Disk & 860 & 23.2 & 89.8 & 45.8 & 1065 \\
\hline Plow (20 cm)-(Control) & 1750 & 25.9 & 100.0 & 45.1 & 1169 \\
\hline Plow (30 cm) & 1820 & 26.0 & 100.3 & 44.3 & 1150 \\
\hline Spring plowing & 1420 & 24.3 & 93.9 & 45.2 & 1101 \\
\hline Plow 20 cm/Disk & 1250 & 25.1 & 97.0 & 45.5 & 1144 \\
\hline Plow 30 cm /Disk & 1350 & 25.7 & 99.4 & 44.7 & 1152 \\
\hline Plow 20 cm/Disk (2) & 1102 & 25.5 & 98.6 & 44.8 & 1143 \\
\hline Plow 30 cm /Disk (2) & 1230 & 25.3 & 97.5 & 44.0 & 1112 \\
\hline Plow 20 cm/Disk (3) & 853 & 24.6 & 95.1 & 45.7 & 1125 \\
\hline Plow 30 cm/Disk (3) & 925 & 24.6 & 95.1 & 45.4 & 1116 \\
\hline LSD $\mathrm{P}<0.05 \%$ & & 2.3 & & & \\
\hline
\end{tabular}

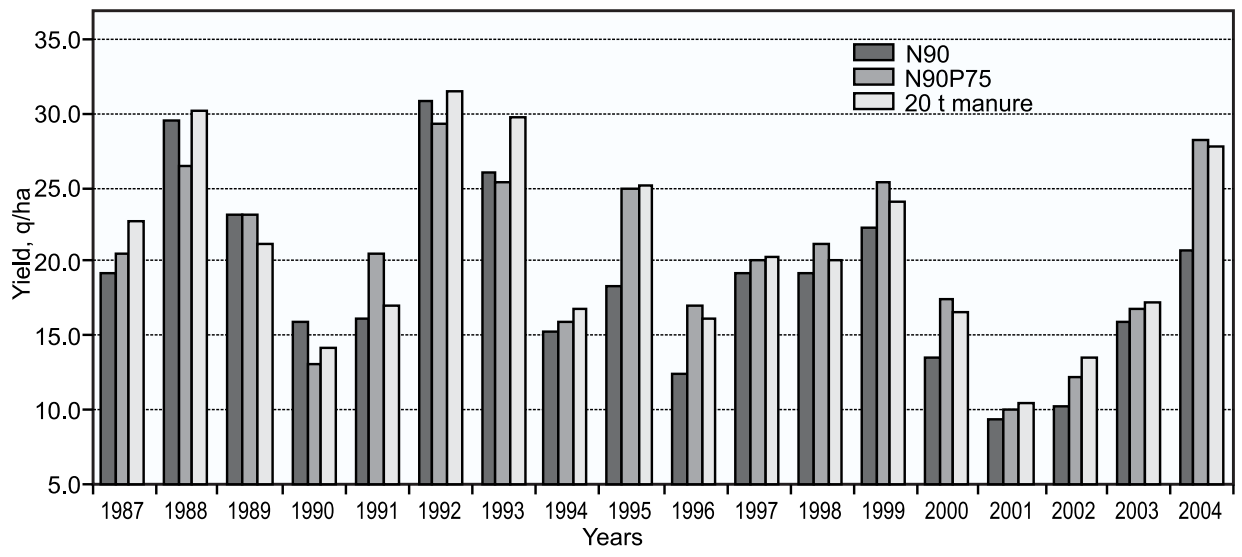

Figure 4: The tendency of fertilization on sunflower yield under autumn plowed variant

In the case of the different fertilizers applied to the plowed variant, it is obvious the effect of weather conditions (Figure 1) and fertilization type (Figute 4). In a wet 
year such as 1991, the grain yield from the plowed and manured variant was reduced due to the nutrient leaching from manure.

The reductions in seed yield observed in 2000, 2001 and 2002 can be attributed to the negative effects of the low rainfall received by sunflower plants during growing season, which affected plant growth and, consequently, their performance (Figure 4).

\section{CONCLUSIONS}

1. The root system of the sunflower is a dynamic system with different possibilities of adaptation to unfavorable soil and weather conditions.

2. Soil compaction determines controls/causes reduction of both, biomass accumulation in the root and grains yield per plant.

3. In the case of disking applied to the soil, similar conditions are registered for the growth and activity of the root system as in the case of soil compacting with similar effects on the yield.

4. Type of fertilization determines the yield increasing in connection with weather conditions.

\section{REFERENCES}

Ardell D. Halvorson, Alfred L. Black, Joseph M. Krupinsky, Steven D. Merrill, and Donald L. Tanaka, 1999. Sunflower Response to Tillage and Nitrogen Fertilization under Intensive Cropping in a Wheat Rotation. Agronomy Journal 91: 637-642

Ardell D. Halvorson, Alfred L. Black, Joseph M. Krupinsky, Steven D. Merrill, Brian J. Wienhold, and Donald L. Tanaka, 2000. Spring Wheat Response to Tillage and Nitrogen Fertilization in Rotation with Sunflower and Winter Wheat. Agronomy Journal 92: 136144

Barnes, K.K., Carleton, W.A., Taylor, H.M., Throckmorton, R.I., 1971. Compaction of agricultural soils. ASAE Monograph. U.S.A.

Boone, F.R., 1986. Towards soil compaction limits for crop growth Neth. J. Agric. Sci. 34: 349360.

Eriksson, J., Hakansson, I., Danfors, B., 1974. The effect of soil compaction on soil structure and crop yields. Sweed. Inst. Agric. Eng., Uppsala Rep. pp. 354.

Hakansson, I., Woorhees, W., Hugh, R., 1988. Vehicle and wheel factors influencing soil compaction and crop response in different traffic regimes. Soil Res. 11:239-282.

Loyd R. Stone, Dwayne E. Goodrum, Mahmad Nor Jaafar, and Akhter H. Khan, 2000. Rooting Front and Water Depletion Depths in Grain Sorghum and Sunflower. Agronomy Journal 93: 1105-1110

Michael P. Bange, Graeme L. Hammer, Stephen P. Milroy, and Kenneth G. Rickert, 2000. Improving Estimates of Individual Leaf Area of Sunflower. Agronomy Journal 92: 761765

Russell Scott, 1977. Plant root system: Their function and interaction with the soil, Publish. Mc Grow-Hill Book Comp. Limited, pp. 144-152.

Sin, Gh., Ionita, St., Terbea Maria, Boruga, I., 1989. Einfluss der Bodenverdichtung auf Wachstum und Ertrag von Feldkulturen und auf einge Parameter beim Pflügen. Wiss. Tagung des FZB - Müncherberg, DDR, pp. 181-188.

Sin, Gh., Ionita, St., Terbea Maria, Petcu, Gh., 1991. Sunflower response to soil compaction. Proceedings of the International Conference of Sunflower, Pisa, Italy, pp. 422-427. 
Soane, B.D., Dickson, J.W., Campbell, D.J., 1982. Compaction by agricultural vehicles: a review III. Incidence and control of compassion in crop production. Soil Tillage Research 2: 336.

\title{
INFLUENCIA DE LAS MEDIDAS AEROTÉCNICAS Y FERTILIZACIÓN EN EL RENDIMIENTO DE GIRASOL EN LOS EXPERIMENTOS A LARGO PLAZO
}

RESUMEN

Los experimentos en campo fueron llevados a cabo en el período de 1980 a 2004 en el Instituto de Investigaciones y Desarrollo Agrícolas en Fundulea (Rumunía) en el chernoziom empobrecido, filtrante, formado en loess, con el contenido de arcilla de $33 \%$ y $2.8 \%$ de materia orgánica en el estrato cultivable. En el trabajo se considera la influencia de diferentes métodos de labranza de tierra (arado de vertedera, escoplo, subsolador, disqueo), fertilización y los pasos consecutivos con el tractor ( 1 a 3 veces antes de la preparación de presembrado en el rendimiento de girasol, cultivado en la labranza seca). Las nuevas, modernas tecnologías de producción de plantaciones deben ser adelantadas, como respuesta a reflexión sobre la influencia de la agricultura en el entorno, en la dirección de disminución de intensidad de la producción. En ese contexto, la elección del favorable método de labranza de tierra, es una decisión importante, con la cual pueden mejorarse el rendimiento y la calidad del grano. La aplicación continua de las dosis de fertilizantes óptimas (minerales y orgánicos) nos ayudó a desarrollar los sistemas de cultivo de girasol más eficaces. Las ruedas de las máquinas agricultoras causan la compresión del suelo hasta una profundidad de $40 \mathrm{~cm}$, incrementada por el aumento de volumen y disminución de la porosidad total y la porosidad aérea debajo del mínimo aceptable para el desarrollo normal de las plantas. La altura de la planta y la superficie de hoja, son disminuidas por la compresión del suelo, como resultado de las empeoradas condiciones del suelo para el desarrollo de la raíz. La biomasa de la raíz ha sido disminuida por $16-33 \%$ en el suelo comprimido, en comparación con el no comprimido.

\section{EFFET DES MESURES AGRICOLES ET DES FERTILISANTS SUR LES RENDEMENTS DE TOURNESOL DANS LES EXPÉRIENCES À LONG TERME.}

\author{
RÉSUMÉ
}

Des expériences sur un chernozem appauvri, bien drainé, formé sur le loess avec un contenu d'argile de $33 \%$ et $2,8 \%$ de matière organique sur une couche arable ont été effectuées dans les champs de 1980 à 2004 à l'Institut de recherche et de développement agricole de Fundulea (Roumanie). Cet article présente l'effet de différentes méthodes de labourage (charrue à soc, chisel, paraplow, disking), fertilisants et passages successifs du tracteur rangée par rangée (de 1 à 3 ) avant la préparation du sol sur le rendement du tournesol cultivé dans des conditions de terre sèche. Il faut améliorer les nouvelles technologies de production pour répondre aux inquiétudes concernant les effets de l'agriculture sur l'environnement en réduisant l'intensification de la culture. Dans ce contexte, le choix d'une bonne méthode de labourage est important et 
il peut améliorer la production et la qualité des récoltes. Une application constante des doses optimales de fertilisants (minéraux et organiques) contribue au développement d'un système de culture du tournesol plus efficace. La pression exercée par les roues cause une compression du sol jusqu'à $40 \mathrm{~cm}$ de profondeur, ce qui est renforci par une augmentation de la densité de la masse et une diminution de la porosité totale et de la porosité de l'air jusque sous le minimum acceptable pour le développement des plantes. La hauteur de la plante et la surface de la feuille ont diminué à cause de la compression qui forme un sol moins propice au développement des racines. Dans le sol comprimé la biomasse des racines était inférieure de $16-33 \%$ à celle des racines dans un sol non comprimé. 